\title{
T-Box Transcription Factor TBX5
}

National Cancer Institute

\section{Source}

National Cancer Institute. T-Box Transcription Factor TBX5. NCI Thesaurus. Code C92150.

T-box transcription factor T BX5 (518 aa, $\sim 58 \mathrm{kDa}$ ) is encoded by the human TBX5 gene.

This protein is involved in the regulation of both mesoderm differentiation and transcription. 